Lea Nia, Riris Loisa: Pengaruh Penggunaan New Media Terhadap Pemenuhan Kebutuhan (Studi Tentang Media Sosial Facebook Dalam Pemenuhan Informasi Di Kalangan Ibu Rumah Tangga)

\title{
Pengaruh Penggunaan New Media Terhadap Pemenuhan Kebutuhan (Studi Tentang Media Sosial Facebook Dalam Pemenuhan Informasi di Kalangan Ibu Rumah Tangga)
}

\author{
Lea Nia, Rirs Loisa \\ Leania1316@gmail.com,ririsl@fikom.untar.ac.id
}

Fakultas Ilmu Komunikasi Universitas Tarumanagara

\begin{abstract}
Initially, the media is something that is controlled by the owners, namely the parties concerned. But after internet technology was created, new media made people have their own accounts and create their own content. This Thesis Research aims to determine the effect of Facebook Use on Meeting Information Needs and why housewives use Facebook as a means of meeting their information needs, this can later be measured and described. This research is based on the number of housewives who are seen using Facebook to search for information instead of the Google search engine. Some of the concepts used as the basis for this research are the use of the internet, meeting needs, new media, and social media. The theory used in this research is the uses and gratification theory, the theory of alleged values, and new media theory. The approach used is a mix-method, which is a combination of quantitative and qualitative approaches, and uses a case study method. The conclusion in this study is that there is an influence of the variable Facebook Usage on Meeting the Needs of Information among Housewives, as well as the most common reasons housewives choose Facebook because it feels more familiar, easy, and complete.
\end{abstract}

Keywords: housewives, information, New Media, social media Facebook

\begin{abstract}
Abstrak
Pada awalnya, media adalah sesuatu yang dikendalikan oleh para pemiliknya, yakni kaum yang berkepentingan. Namun setelah teknologi internet tercipta, media baru membuat orang memiliki akunnya sendiri dan menciptakan konten mereka masing-masing. Penelitian Skripsi ini bertujuan untuk mengetahui pengaruh Penggunaan Facebook terhadap Pemenuhan Kebutuhan Informasi dan mengapa ibu rumah tangga menggunakan Facebook sebagai sarana pemenuhan kebutuhan informasi mereka, hal ini nantinya dapat diukur dan di deskripsikan. Penelitian ini didasari banyaknya ibu rumah tangga yang terlihat menggunakan Facebook untuk mencari informasi alih-alih mesin pencarian Google. Beberapa konsep yang dijadikan landasan dalam penelitian ini adalah penggunaan internet, pemenuhan kebutuhan, new media, dan media sosial. Teori yang digunakan dalam penelitian ini adalah teori uses and gratification, teori nilai dugaan, dan teori media baru. Pendekatan yang digunakan adalah pendekatan campuran (mix-method), yaitu penggabungan dari pendekatan kuantitatif dan kualitatif, dan menggunakan metode studi kasus. Kesimpulan dalam penelitian ini adalah ada pengaruh dari variabel Penggunaan Facebook terhadap Pemenuhan Kebutuhan Informasi di Kalangan Ibu Rumah Tangga, serta alasan yang paling umum ibu rumah tangga memilih Facebook karena dirasa lebih familiar, mudah, dan lengkap.
\end{abstract}

Kata Kunci: housewives, information, New Media, social media Facebook 


\section{Pendahuluan}

Teknologi pada saat ini berkembang dengan sangat pesat, banyak produk teknologi diciptakan untuk memberikan kemudahan kepada masyarakat. Salah satunya adalah media baru. Media baru didefinisikan sebagai produk komunikasi yang termediasi teknologi, terdapat bersama dengan computer digital (Creeber dan Martin, 2009). Media baru diyakini sebagai media terkini yang bersifat cepat dalam menyampaikan informasi. Berikut ini adalah jenis-jenis media baru:

1) Media komunikasi interpersonal, komunikasi interpersonal meliputi telepon, terutama handphone dan E-mail, terutama untuk aktivitas kerja, yang kini semakin personal. 2). Media permainan interaktif, media permainan interaktif biasanya berkaitan dengan komputer dan juga video games, dan peralatan virtual reality. 3). Media pencari informasi, media pencari informasi meliputi kategori yang luas, tetapi internet atau world wide web adalah contoh yang paling signifikan. Internet dapat dilihat sebagai perpustakaan dan sumber data yang ukurannya sangat besar, sangat sering diperbaharui, dan mudah diakses. 4) Media partisipasi kolektif, media partisipasi kolektif adalah kategori yang khusus melingkupi penggunaan internet untuk berbagi dan bertukar informasi, ide, dan pengalaman, serta pengembangan aktif relasi pribadi (yang dimediasi oleh komputer). Penggunaan media jenis ini meliputi jangkauan yang luas, mulai untuk mencari informasi belaka sampai dengan hubungan yang sangat emosional. (McQuail, 2005). Media sosial juga bersifat global dimana siapapun dapat terlibat berinteraksi (Setyanto, 2016).

Menurut wearesocial (2019) media sosial khususnya social networking terpopuler per satu Januari 2019 di dunia adalah Facebook, Youtube, dan Instagram. Namun di Indonesia pengguna terbanyak untuk social networking adalah Youtube, Facebook, dan Instagram. Youtube dan Instagram lebih banyak digunakan oleh anak muda untuk mendapatkan informasi yang mereka inginkan, sedangkan Facebook digunakan hampir oleh semua usia. Dari usia remaja (13 sampai 17 tahun) sampai ke usia tua (45 sampai 54 tahun) termasuk kedalam pengguna aktif Facebook. Ada banyak alasan mengapa banyak orang menggunakan Facebook, salah satunya adalah kemudahan dalam mencari dan mendapatkan informasi yang pengguna perlukan.

Berdasarkan Latar Belakang yang sudah dipaparkan, maka rumusan masalahnya adalah sebagai berikut: 1. Apakah ada pengaruh antara media sosial Facebook terhadap pemenuhan kebutuhan informasi ibu rumah tangga? 2. Mengapa Ibu Rumah Tangga menggunakan media sosial Facebook untuk memenuhi kebutuhan informasi harian mereka? 3. Bagaimana Ibu Rumah Tangga menggunakan Facebook dalam mencari dan memenuhi kebutuhan informasi mereka?

Variabel yang menjadi fokus penelitian ini adalah variabel $\mathrm{X}$, yakni Penggunaan Facebook dan variabel Y, yakni Pemenuhan kebutuhan informasi. Facebook adalah salah satu sosial media yang memiliki banyak fungsi, salah satunya adalah untuk memenuhi informasi.

Hipotesis dalam penelitian ini adalah $\mathrm{H} 0=$ Tidak ada pengaruh Penggunaan Facebook (X) terhadap Pemenuhan Kebutuhan Informasi $(\mathrm{Y})$ dan $\mathrm{Ha}=$ Ada pengaruh Penggunaan Facebook (X) terhadap Pemenuhan Kebutuhan Informasi (Y). Sedangkan Berdasarkan dengan Latar Belakang dan Rumusan Masalah yang dimuat, tujuan penelitian yang hendak dicapai adalah 1 . Untuk mengetahui apakah ada pengaruh Penggunaan Facebook terhadap Pemenuhan Informasi di kalangan Ibu Rumah Tangga. 2. Untuk mengetahui mengapa ibu rumah tangga menggunakan Facebook untuk memenuhi kebutuhan informasi. 3. Untuk mengetahui jenis-jenis informasi apa 
Lea Nia, Riris Loisa: Pengaruh Penggunaan New Media Terhadap Pemenuhan Kebutuhan (Studi Tentang Media Sosial Facebook Dalam Pemenuhan Informasi Di Kalangan Ibu Rumah Tangga)

saja yang dicari Ibu rumah tangga di media sosial Facebook. Dan teori yang digunakan dalam penelitian ini adalah teori penggunaan dan pemenuhan kebutuhan (uses and gratification theory), teori nilai dugaan (expectancy-value theory), teori media baru (new media theory).

\section{Metode Penelitian}

Ditinjau dari jenis datanya, penelitian ini menggunakan pendekatan campuran (mix-method), yaitu penelitian yang menggabungkan dua bentuk pendekatan, yakni kuantitatif dan kualitatif. Menurut Sugiyono (2011) mix method mengkombinasikan dua metode penelitian, yaitu kuantitatif dan kualitatif ke dalam suatu kegiatan penelitian, sehingga data yang diperoleh akan lebih komprehensif, valid, reliabel dan objektif. Dalam penelitian ini, menggunakan metode penelitian studi kasus. Jenis metode penelitian ini berupaya untuk mengembangkan pemahaman dengan cara mendeskripsikan secara mendalam sebuah kasus yang menjadi fokus penelitian. Sesuai dengan pengertian diatas, menghitung pengaruh dan memahami mengapa ibu rumah tangga memilih Facebook sebagai sarana pemenuhan informasi adalah tujuan dari penelitian ini. Populasi adalah wilayah generalisasi yang terdiri atas subjek atau objek yang mempunyai kualitas dan karakteristik tertentu yang ditetapkan peneliti untuk dipelajari dan kemudian ditarik kesimpulannya (Sugiyono, 2010). Dalam penelitian ini, populasi yang dimaksud adalah Ibu Rumah tangga pengguna media sosial Facebook. Saat ini jumlah pengguna media sosial Facebook mencapai 120 juta users, dan sebanyak 22 jutanya adalah ibu rumah tangga. Menurut Sugiyono (2010) "sampel adalah bagian dari jumlah dan karakteristik yang dimiliki oleh populasi tersebut." Teknik sampling yang digunakan dalam penelitian ini adalah teknik sampling Non-Probability Sampling atau Non Random Sampling, yaitu teknik pengambilan sampel yang tidak dilakukan secara acak. Peneliti khususnya menggunakan teknik Purposive Sampling, yaitu teknik ini memilih sampel berdasarkan kriteria yang telah ditentukan oleh peneliti. Sampel dalam penelitian ini adalah Ibu rumah tangga berusia 18 tahun sampai 55 tahun, yang tidak bekerja, dan aktif menggunakan media sosial Facebook.

Teknik pengumpulan data yang dilakukan adalah menggunakan tiga metode, yaitu Kuesioner atau angket, wawancara, dan studi kepustakaan. Menurut Kusumah (2011) kuesioner adalah daftar pertanyaan tertulis yang diberikan kepada subjek yang diteliti untuk mengumpulkan informasi yang dibutuhkan peneliti. Bentuk kuesioner ada dua macam, yaitu kuesioner berstruktur atau tertutup dan kuesioner tidak berstruktur atau terbuka. Dalam teknik ini, peneliti mengajukan sejumlah pertanyaan tertulis kepada responden, dengan harapan peneliti bisa mendapatkan data yang akurat mengenai pengaruh penggunaan Facebook terhadap Pemenuhan Kebutuhan Informasi, dari sampel yang telah ditentukan sebanyak 100 responden ibu rumah tangga pengguna Facebook. Lalu, yang kedua adalah Wawancara. Wawancara adalah teknik pengambilan data melalui pertanyaan yang diajukan secara lisan kepada responden. Dalam hal ini, peneliti mengajukan sejumlah pertanyaan lisan terkait kasus yang sedang diteliti kepada ibu rumah tangga. Dan mengajukan pertanyaan mengenai hal ini kepada ahli media sosial untuk bisa memperoleh data yang lebih signifikan. Dan teknik ketiga adalah studi kepustakaan adalah kajian teoritis, referensi serta literatur ilmiah lainnya yang berkaitan dengan budaya, nilai dan norma yang diteliti pada situasi sosial (Sugiyono, 2014). Studi kepustakaan ini mencari dan menelaah data yang hendak diteliti secara teoritis. Studi kepustakaan menggunakan data yang berasal 
dari buku, jurnal, makalah, laporan penelitian, dan hasil penelitian lain yang memiliki bahasan yang serupa.

Teknik pengolahan dan analisis data adalah teknik mengolah dan menganalisis data-data yang sudah dikumpulkan. Untuk menganalisis dua jenis data kuantitatif dan kualitatif, maka digunakan analisis yang sesuai dengan metode penelitian, yaitu dua metode penelitian dengan desain penelitian sequential explanatory. Dalam hal ini, analisis data kuantitatif dijadikan sebagai metode pertama sedangkan analisis data kualitatif menjelaskan lebih dalam tentang data kuantitatif.

\section{Hasil Temuan dan Diskusi}

\section{Koefisien Korelasi}

Tabel 1. Koefisien Korelasi

\begin{tabular}{llcc}
\hline & \multicolumn{1}{c}{$\begin{array}{c}\text { Penggunaan } \\
\text { Facebook }\end{array}$} & $\begin{array}{c}\text { Pemenuhan Kebutuhan } \\
\text { Informasi }\end{array}$ \\
\hline $\begin{array}{l}\text { Penggunaan } \\
\text { Facebook }\end{array}$ & $\begin{array}{l}\text { Pearson } \\
\text { Correlation }\end{array}$ & 1 & $.428^{*}$ \\
\cline { 2 - 4 } & Sig. (2-tailed) & 100 & .042 \\
\hline $\begin{array}{l}\text { Pemenuhan } \\
\text { Kebutuhan }\end{array}$ & Pearson & $.428^{*}$ & 23 \\
Informasi & Correlation & & 1 \\
\cline { 2 - 4 } & Sig. (2-tailed) & .042 & \\
\hline
\end{tabular}

*. Correlation is significant at the 0.05 level (2-tailed).

Sumber: Hasil pengolahan SPSS 25

Sesuai dengan tabel diatas, korelasi antara variabel Penggunaan Facebook (X) dan pemenuhan kebutuhan informasi (Y) adalah 0,428. Sesuai dengan teori, dapat dikatakan koefisien korelasinya berada pada tingkat sedang, sedangkan tanda bintang pada tabel menjelaskan jika semakin tinggi Penggunaan Facebook (X) maka semakin tinggi juga Pemenuhan Kebutuhan Informasi (Y).

\section{Analisis Regresi Linear Sederhana}

Tabel 2. Analisis Regresi Linear Sederhana

\begin{tabular}{|c|c|c|c|c|c|c|}
\hline \multirow{2}{*}{\multicolumn{2}{|c|}{ Model }} & \multicolumn{2}{|c|}{$\begin{array}{c}\text { Unstandardized } \\
\text { Coefficients }\end{array}$} & \multirow{2}{*}{$\begin{array}{l}\text { Standardized } \\
\text { Coefficients } \\
\text { Beta }\end{array}$} & \multirow[b]{2}{*}{$\mathrm{T}$} & \multirow[b]{2}{*}{ Sig. } \\
\hline & & $\mathrm{B}$ & Std. Error & & & \\
\hline \multirow[t]{2}{*}{1} & (Constant) & 11.143 & 3.404 & & 3.274 & .001 \\
\hline & $\begin{array}{l}\text { Penggunaan } \\
\text { Facebook }\end{array}$ & 1.152 & .077 & .833 & 14.896 & .000 \\
\hline
\end{tabular}

a. Dependent Variable: Pemenuhan Kebutuhan Informasi

Sumber: Hasil pengolahan SPSS 25

Keterangan: $\mathrm{a}=$ Angka konstan dari Unstandardized Coefficients. Dalam kasus ini nilainya sebesar 11.143X. Angka ini merupakan angka konstan yang mempunyai arti bahwa jika tidak ada Penggunaan Facebook(X), maka nilai konsisten Pemenuhan Kebutuhan Informasi (Y) adalah sebesar 11.143. b = Angka koefisien regresi. Nilainya sebesar 1.152. Angka ini mengandung arti bahwa setiap penambahan $1 \%$ tingkat Penggunaan Facebook (X), maka Pemenuhan Kebutuhan Informasi (Y) 
Lea Nia, Riris Loisa: Pengaruh Penggunaan New Media Terhadap Pemenuhan Kebutuhan (Studi Tentang Media Sosial Facebook Dalam Pemenuhan Informasi Di Kalangan Ibu Rumah Tangga)

akan meningkat sebesar 1.152. Karena koefisien regresi bernilai (+), maka dengan demikian dapat dikatakan bahwa Penggunaan Facebook (X) berpengaruh positif terhadap Pemenuhan Kebutuhan Informasi (Y). Sehingga persamaan regresinya adalah $\mathrm{Y}=11.143+1.152 \mathrm{X}$.

\section{Uji Hipotesis Membandingkan Nilai Sig. dengan 0,05}

Yang menjadi dasar pengambilan keputusan dalam analisis regresi dengan melihat nilai signifikan (Sig.) hasil output SPSS adalah:

a. Jika nilai signifikan (Sig.) lebih kecil < dari probabilitas 0,05 mengandung arti bahwa ada pengaruh variabel $(\mathrm{X})$ terhadap variabel $(\mathrm{Y})$.

b. Sebaliknya, jika nilai signifikansi (Sig.) lebih besar >dari probabilitas 0,05 mengandung arti bahwa tidak ada pengaruh variabel $(\mathrm{X})$ terhadap variabel $(\mathrm{Y})$.

Tabel 3. Analisis Signifikansi

\begin{tabular}{|c|c|c|c|c|c|c|}
\hline \multicolumn{7}{|c|}{ Coefficients $^{\mathrm{a}}$} \\
\hline \multirow[b]{2}{*}{ Model } & & \multicolumn{2}{|c|}{$\begin{array}{c}\text { Unstandardized } \\
\text { Coefficients }\end{array}$} & $\begin{array}{c}\text { Standardized } \\
\text { Coefficients } \\
\end{array}$ & & \multirow[b]{2}{*}{ Sig. } \\
\hline & & B & Std. Error & Beta & & \\
\hline$\overline{1}$ & (Cons & 11.143 & 3.404 & & 3.274 & .001 \\
\hline & Penggunaan Facebook & 1.152 & .077 & .833 & 14.896 & .000 \\
\hline
\end{tabular}

a. Dependent Variable: Pemenuhan Kebutuhan Informasi

Sumber: Hasil pengolahan SPSS 25

Berdasarkan ouput diatas diketahui nilai signifikansi (Sig.) sebesar 0,000 lebih kecil dari < probabilitas 0,05, sehingga dapat disimpulkan bahwa H0 ditolak dan $\mathrm{Ha}$ diterima, yang berarti bahwa "Ada pengaruh penggunaan Penggunaan Facebook (X) terhadap Pemenuhan Kebutuhan Informasi (Y)".

\section{Koefisien Determinasi}

Tabel 4. Koefisien Determinasi

\begin{tabular}{lllll}
\hline \multicolumn{3}{l}{ Model Summary } & & \\
\hline Model & R & R Square & Adjusted R Square & Std. Error of the Estimate \\
\hline 1 & $.833^{\mathrm{a}}$ & .694 & .691 & 3.96577 \\
\hline a. Predictors: (Constant), Penggunaan Facebook & \\
\hline
\end{tabular}

Sumber: Hasil pengolahan SPSS 25

$\mathrm{R}^{2}(\mathrm{R}$ Square $)=0,694$

Koefisien Determinasi $=\mathrm{R}^{2}$ X $100 \%=69,4 \%$

Dari output diatas diketahui nilai $\mathrm{R}$ Square sebesar 0,694. Nilai ini mengandung arti bahwa pengaruh Penggunaan Facebook (X) terhadap Pemenuhan Kebutuhan Informasi (Y) adalah sebesar 69,4 \% sedangkan 30,6\% Pemenuhan Kebutuhan Informasi dipengaruhi oleh variabel yang tidak diketahui (faktor lain).

\section{Penggunaan Media Sosial Facebook oleh Ibu Rumah Tangga}

Teori uses and gratification memiliki lima landasan utama yang menjelaskan bagaimana teori itu terjadi dalam masyarakat. Yang pertama adalah khalayak adalah aktif dan penggunaan didasarkan atas tujuan tertentu. Berdasarkan teori yang dikembangkan, peneliti bertanya kepada informan mengenai topik tersebut. Dalam menggunakan media sosial Facebook, ibu rumah tangga aktif menggunakan akun 
Facebook mereka, mereka juga menggunakan Facebook untuk tujuan tertentu. Diketahui bahwa ibu rumah tangga memiliki beberapa tujuan ketika menggunakan Facebook, salah satunya adalah pemenuhan kebutuhan informasi, selain itu ibu rumah tangga juga menggunakan Facebook sebagai sarana komunikasi mereka dengan teman-teman mereka, dan juga sebagai sarana hiburan atau kesenangan. Informasi yang biasa dicari adalah informasi yang biasanya berguna untuk ibu rumah tangga, yang biasanya adalah informasi berupa resep masakan, parenting, berita viral, tips and trick rumah tangga, dan juga informasi harian yang memang dibutuhkan oleh semua individu. Sedangkan, untuk sarana komunikasi, ibu rumah tangga menggunakan Facebook untuk bertukar kabar dengan teman mereka, menuliskan status, membagikan foto, dan bertemu dengan teman lama mereka. Lalu, untuk sarana hiburan, biasanya para ibu mencari video yang viral atau hal-hal lucu.

Landasan kedua adalah inisiatif dalam menghubungkan kebutuhan dan kepuasan untuk pilihan media spesifik ada pada khalayak. Ibu rumah tangga tentunya memilih media spesifik (Facebook) karena mereka merasa kebutuhannya terpuaskan. Alasan mengapa ibu rumah tangga memilih menggunakan Facebook adalah karena mereka merasa jika Facebook memberikan pemenuhan kebutuhan informasi yang mereka inginkan, selain itu informasi yang tersaji dalam Facebook juga dapat dikatakan lengkap. Selain kepuasan dari segi informasi, ibu rumah tangga berpendapat kalau Facebook juga memberikan mereka kemudahan dalam penggunaan Facebook. Banyak ibu rumah tangga setuju kalau tampilan Facebook memudahkan mereka dibandingkan dengan media sosial lain, sehingga mereka merasa lebih akrab dan lebih bisa mengandalkan Facebook sebagai sarana pemenuhan informasi. Media bersaing dengan sumber-sumber lain dalam pemenuhan kebutuhan dan kepuasan. Sesuai dengan pernyataan yang dilontarkan ahli media sosial, Abang Edwin Syarif Agustin, memang banyak sekali informasi yang bisa didapatkan lewat media lain, tapi kembali lagi, semua hal itu berhubungan dengan kenyamanan si pengguna. Dalam pemenuhan informasi, Facebook memang dapat dikatakan lengkap, hampir semua yang dicari bisa ditemukan di Facebook, dan jika dibandingkan dengan media sosial lain, seperti Instagram dan Twitter yang tampilannya lebih sulit, tentunya ibu rumah tangga pasti akan memilih Facebook, ditambah pada media sosial lain juga informasinya memang tidak selengkap Facebook. Lalu, pada poin landasan keempat, Khalayak memiliki kesadaran diri yang cukup terhadap penggunaan media, kepentingan dan motif atas pilihan media tertentu sehingga dapat memberikan penjelasan yang akurat tentang hal tersebut. Hal ini sesuai dengan fungsi media itu sendiri, dan dalam penelitian ini ibu rumah tangga memiliki kesadaran dalam menggunakan Facebook berdasarkan kepentingan dan motif mereka atas pilihan mereka ketika memilih Facebook sebagai sarana pemenuhan informasi. Banyak dari ibu rumah tangga menggunakan Facebook, sehingga mereka dapat menjabarkan pengalaman mereka ketika menggunakan media sosial ini.

Penilaian terhadap konten suatu media hanya dapat dilakukan oleh khalayak, hal ini selaras dengan kuesioner yang peneliti bagikan mengenai kepercayaan ibu rumah tangga terhadap informasi yang ada di dalam Facebook. Sebagian dari mereka, merasa kalau informasi dari Facebook tidak kredibel, hal ini tidak lepas dari dari citra yang memang sudah melekat pada Facebook bahwa didalamnya terdapat banyak berita tidak benar meski tidak semuanya. Selaras dengan poin diatas, tentunya penilaian ibu rumah tangga terhadap Facebook tidak dapat diatur oleh siapapun, bahkan oleh Facebook itu sendiri. Pendapat ini didukung juga oleh pakar media sosial 
Lea Nia, Riris Loisa: Pengaruh Penggunaan New Media Terhadap Pemenuhan Kebutuhan (Studi Tentang Media Sosial Facebook Dalam Pemenuhan Informasi Di Kalangan Ibu Rumah Tangga)

Abang Edwin Syarif Agustin yang menyatakan bahwa kepercayaan seseorang terhadap media sosial tergantung bagaimana citra media sosial itu sendiri.

\section{Pemenuhan Kebutuhan Informasi lewat Facebook}

Sesuai dengan teori pengharapan nilai yang menyatakan khalayak memilih media berdasarkan nilai yang mereka anut, maka bisa dikatakan bahwa ibu rumah tangga memilih Facebook sebagai sarana pemenuhan informasi bukan tanpa alasan. Yang menjadi alasannya adalah karena ibu rumah tangga merasa Facebook adalah salah satu platform yang tidak asing bagi mereka. Pada dasarnya, manusia adalah makhluk yang malas untuk belajar hal-hal baru jika sudah nyaman, hal inilah yang membuat kebanyakan ibu rumah tangga memilih Facebook ketimbang media sosial lain, karena mereka sudah terbiasa menggunakan. Abang Edwin, selaku pakar media sosial juga mengatakan hal yang selaras, karena nature manusia memang begitu, agak sulit membuka diri pada hal baru jika sudah nyaman di satu tempat. Selain karena faktor nyaman, yang membuat ibu rumah tangga merasa puas terhadap media sosial Facebook adalah karena informasi mereka terpenuhi. Ibu rumah tangga merasa Facebook memberikan segala hal yang mereka butuhkan. Sesuai hasil kuesioner, banyak di antara ibu rumah tangga yang mengatakan bahwa informasi di dalam Facebook cukup lengkap, meski tidak semua informasi dapat dipercaya.

\section{Mencari dan Memenuhi Kebutuhan Informasi.}

1. Menggunakan status, Facebook adalah satu dari banyak media sosial yang bisa dikatakan berhasil dalam membangun sebuah hubungan (komunikasi), inilah yang nantinya digunakan untuk memenuhi kebutuhan informasi. Caranya adalah seorang user menulis status berisi hal yang dipertanyakan, kemudian membiarkan teman-temannya menjawab pertanyaan yang diajukan lewat kolom komentar. Hal ini selaras dengan yang terdapat dalam teori media baru, yakni bersifat user generated content, khalayak menulis sendiri isi konten berdasarkan hal yang mereka inginkan, tanpa bisa diatur dan di monopoli oleh pihak tertentu.

2. Kolom pencarian, Kolom pencarian atau Fitur searching dalam media sosial merupakan salah satu hal yang populer. Fitur ini membantu para pengguna menemukan apa yang mereka cari dengan mudah. Dalam Facebook, fitur pencarian bisa terbagi lagi. Misal, kita mengetikkan sebuah kata, di dalam Facebook terdapat beberapa pilihan, apakah khalayak mencari sebuah nama, sebuah status, pages, dan banyak lagi pilihannya. Fitur inilah yang dimanfaatkan ibu rumah tangga untuk mencari informasi, mereka mengetikkan yang mereka ingin ketahui lewat kolom pencarian yang tersedia, dan semua yang berkaitan dengan kata kuncinya akan terpampang di layar.

3. Fitur Share and Save, Share adalah salah satu fitur dalam Facebook yang bisa digunakan untuk membagikan postingan orang lain lewat akun yang dimiliki. Fitur ini dapat membuat teman yang dimiliki dalam akun Facebook melihat apa yang dibagikan. Jadi dari satu sumber bisa dibagikan kepada banyak orang lainnya seperti rantai. Fitur share ini tentunya digunakan para ibu rumah tangga untuk membagikan informasi yang mereka terima pada teman-temannya. Selain fitur share, terdapat juga fitur save atau simpan. Di dalam Facebook jika merasa sebuah postingan orang lain adalah penting, dan atau tertarik untuk membacanya di lain waktu, bisa menggunakan fitur ini. Fitur ini bermanfaat bagi ibu rumah tangga yang melihat informasi, tapi berniat membacanya lagi nanti. Contohnya seperti sebuah resep. Banyak ibu rumah 
tangga tertarik dengan resep masakan tertentu, tapi karena belum berniat membuatnya, mereka menyimpan postingan tersebut, dan membukanya ketika ingin memasak.

\section{Simpulan}

Setelah melakukan penelitian terkait Pengaruh Penggunaan Media Sosial Facebook terhadap Pemenuhan Kebutuhan Informasi di Kalangan Ibu Rumah Tangga, didapat kesimpulan bahwa dalam penerapannya, Penggunaan Facebook dapat memenuhi kebutuhan informasi ibu rumah tangga di Indonesia. Hasil analisis koefisien korelasi menyatakan hubungan antara variabel Penggunaan Facebook (X) dan Pemenuhan Kebutuhan Informasi (Y) ada pada tingkat sedang $\left(0,428^{*}\right)$, tanda bintang pada akhir angka, menyatakan semakin tinggi penggunaan Facebook maka semakin tinggi juga Pemenuhan Kebutuhan Informasi. Berikutnya, nilai yang didapat dari analisis regresi linear adalah $\mathrm{Y}=11.143+1.152 \mathrm{X}$, karena nilainya positif maka Penggunaan Facebook (X) berpengaruh positif terhadap Pemenuhan Kebutuhan Informasi (Y). Kemudian, nilai signifikansi yang didapat adalah $<0,005$, maka dapat dikatakan H0 ditolak dan Ha diterima, yang berarti "Ada pengaruh penggunaan Penggunaan Facebook (X) terhadap Pemenuhan Kebutuhan Informasi (Y)", dan besar pengaruh yang didapat adalah $69,4 \%$ didapatkan dari perhitungan koefisien determinasi.

Terdapat banyak alasan mengapa ibu rumah tangga menggunakan Facebook sebagai sarana pemenuhan informasi mereka. Salah satunya adalah dari segi tampilan Facebook yang terbilang mudah dipahami, alasan kedua adalah karena banyak orang yang memilih Facebook sebagai media sosial pertama mereka, sehingga ibu rumah tangga, khususnya generasi X dan millennials atas merasa Facebook lebih familiar dan tidak sulit. Selain itu, Facebook juga memberikan kemudahan dalam akses informasi, informasi didalamnya cenderung lengkap dan mudah dicari dan mudah disebarkan kepada orang lain. Fitur untuk pemenuhan informasi juga banyak, seperti fitur searching, grup, fanspages, dan bisa lewat Penelitian status. Selain mencari, ibu rumah tangga juga bisa mendapatkan langsung informasi melalui yang di bagikan (share) oleh teman yang ada di dalam Facebook. Selain sebagai penerima informasi pengguna juga bisa menjadi pemberi informasi jika berpartisipasi dalam penyebaran informasi, lewat fitur share. Jenis informasi yang dicari ibu rumah tangga cukup beragam, tapi umumnya berjenis softnews, karena informasi sejenis ini berguna untuk kehidupan rumah tangga yang mereka jalani. Informasi tersebut seperti resep, informasi seputar anak, dan tips and trick untuk rumah tangga, sedangkan untuk berita yang dicari biasanya bukan berita yang punya topik berat, seperti berita tentang kesehatan anak, teknologi saat ini, dan berita sehari-hari.

\section{Ucapan Terima Kasih}

Dengan selesainya penelitian ini, peneliti mengucapkan terima kasih kepada pihak yang secara langsung memberikan kontribusi dalam penelitian ini, yaitu para responden dan informan, pembimbing, dan teman-teman yang membantu yang tidak dapat disebutkan satu persatu. 
Lea Nia, Riris Loisa: Pengaruh Penggunaan New Media Terhadap Pemenuhan Kebutuhan (Studi

Tentang Media Sosial Facebook Dalam Pemenuhan Informasi Di Kalangan Ibu Rumah Tangga)

\section{Daftar Pustaka}

Creeber, G. \& Martin, R. (2009). Digital Cultures: Understanding New Media. Berkshire-England: Open University Press.

Kusumah, Wijaya dan Dedi Dwitagama. 2011. Mengenal Penelitian Tindakan Kelas. Edisi: 2. Jakarta: PT Indeks.

Kemp, Simon (2019, Januari 30). Digital 2019: GLOBAL INTERNET USE ACCELERATES. Agustus 22, 2019. We Are Social database. https://wearesocial.com/blog/2019/01/digital-2019-global-internet-useaccelerates

Kusumah, Wijaya dan Dedi Dwitagama. 2011. Mengenal Penelitian Tindakan Kelas. Edisi: 2. Jakarta: PT Indeks.

McQuail, Denis (2005). Mass Communication Theory. Fifth Edition. London: Sage Publications.

Setyanto, Yugih. (2016). Media Sosial sebagai Sarana Komunikasi Perusahaan dengan Media. Jurnal Komunikasi, 1, 1-3.

Sugiyono. (2011). Metode Penelitian Pendidikan (Pendekatan Kuantitatif, Kualitatif, dan R\&D). Bandung: Alfabeta.

Sugiyono. (2014). Metode Penelitian Kuantitatif Kualitatif dan R\&D. Bandung: Alfabeta. 